\title{
Analysis of the Phylogenetic Relationships of Strains of Burkholderia solanacearum, Pseudomonas syzygii, and the Blood Disease Bacterium of Banana Based on 16S rRNA Gene Sequences
}

\author{
MOHSEN TAGHAVI,,$^{1,2}$ CHRIS HAYWARD,,${ }^{1,2}$ LINDSAY I. SLY, ${ }^{1,2}$ AND MARK FEGAN ${ }^{1 *}$ \\ Cooperative Research Centre for Tropical Plant Pathology ${ }^{1}$ and Department of Microbiology, Centre for Bacterial \\ Diversity and Identification, ${ }^{2}$ The University of Queensland, Queensland 4072, Brisbane, Australia
}

\begin{abstract}
We determined nearly complete 16S rRNA gene sequences for 19 isolates of Burkholderia solanacearum, three isolates of the blood disease bacterium of bananas, and two isolates of Pseudomonas syzygii, the cause of Sumatra disease of cloves. The dendrogram produced by comparing all of these sequences revealed that there were two divisions, which corresponded to the results obtained previously in a restriction fragment length polymorphism analysis (D. Cook, E. Barlow, and L. Sequeira, Mol. Plant Microbe Interact. 2:113-121, 1989) and a total 16S ribosomal DNA (rDNA) sequence analysis of four isolates representing four biovars of $B$. solanacearum (X. Li, M. Dorsch, T. Del Dot, L. I. Sly, E. Stackebrandt, and A. C. Hayward, J. Appl. Bacteriol. 74:324-329, 1993). Division 1 comprised biovars 3, 4, and 5 and an aberrant biovar 2 isolate (strain ACH0732), and division 2 included biovars 1,2 , and $\mathrm{N} 2$, the blood disease bacterium, and $P$. syzygii. Specific nucleotides at positions 458 to 460 (UUC) and 474 (A) characterized division 2, whereas in division 1 the nucleotides at these positions were $A C U$ and $U$, respectively. However, strain $A C H 0732$ had a $U$ at position 458 , as did division 2 isolates, and $G$ instead of $U$ at position 474. Division 2 consisted of two subdivisions; one subdivision contained two $B$. solanacearum isolates that originated from Indonesia, $P$. syzygii strains, and blood disease bacterium strains, and the other subdivision contained all of the other division 2 isolates. Within division 1 , the level of $16 \mathrm{~S}$ rDNA sequence similarity ranged from 99.8 to $100 \%$, and within division 2 , the levels of $16 \mathrm{~S}$ rDNA sequence similarity ranged from 99.1 to $100 \%$. The division 1 isolates exhibited an average level of 16S rDNA sequence similarity to division 2 isolates of $99.3 \%$ (range, 99.1 to $99.5 \%$ ). The occurrence of consistent polymorphisms in the $16 \mathrm{~S}$ rDNA sequences of $B$. solanacearum strains, in particular unique 16S rDNA sequence differences in aberrant biovar 2 isolate $\mathrm{ACH0732}$, and the occurrence of the Indonesian subdivision of division 2 suggest that this group is a rapidly evolving (tachytelic) group.
\end{abstract}

The use of rRNA sequences for classification and identification of microorganisms is now routine, and analysis of $16 \mathrm{~S}$ rRNA gene sequences provides a powerful tool for determining the phylogenetic and evolutionary relationships of microorganisms (34). The rRNA genes are useful molecular chronometers not only because of their conserved nature, high information content, and universal distribution, but also because of the rapidly expanding $16 \mathrm{~S}$ rRNA gene sequence database that can be used for phylogenetic comparisons.

Burkholderia solanacearum causes bacterial wilt of a wide range of crops and is one of the most important disease bacteria in tropical and subtropical regions and some of the warm temperate regions of the world (12). B. solanacearum belongs to pseudomonad rRNA homology group II as determined by rRNA-DNA homology (24) and to the beta subclass of the Proteobacteria $(8,18)$.

$B$. solanacearum is a heterogeneous species which exhibits significant phenotypic diversity $(3,12)$. Traditionally, $B$. solanacearum strains have been divided into five races on the basis of host range and into five biovars on the basis of biochemical properties $(10,12)$. Two clusters of $B$. solanacearum strains have been identified on the basis of restriction fragment length polymorphisms $(3,4)$ and on the basis of the $16 \mathrm{~S}$ ribosomal DNA (rDNA) sequences of four isolates representing biovars $1,2,3$, and 4 (18).

\footnotetext{
${ }^{*}$ Corresponding author.
}

Pseudomonas syzygii, the causal agent of Sumatra disease of cloves (Syzygium aromaticum), is a close relative of $B$. solanacearum, as determined by phenotypic data and DNA-DNA hybridization data (25). The blood disease bacterium (BDB), the causal agent of blood disease of bananas, affects certain members of the Musaceae in Indonesia $(1,6)$. The BDB strains have a distinct host range and several physiological and nutritional characteristics that are quite distinct from characteristics of B. solanacearum $(5,6,28)$. However, partial $16 \mathrm{~S}$ rDNA sequence data for the BDB and $P$. syzygii have confirmed that these organisms are close relatives of $B$. solanacearum (28). Therefore, complete sequence data for the 16S rRNA genes of $P$. syzygii and the BDB could help resolve the relationships of these bacteria and $B$. solanacearum.

\section{MATERIALS AND METHODS}

Bacterial strains. The bacterial isolates used in this study are listed in Table 1 $B$. solanacearum and the BDB isolates were grown on sucrose-peptone agar (10) or tetrazolium chloride plates (16) and were incubated at $28^{\circ} \mathrm{C}$ for 48 to 72 h. $P$. syzygii isolates were cultured on Casamino Acids medium (25).

DNA purification. Genomic DNA was extracted and purified by using two methods, the method of Marmur (21) and the method of Boucher et al. (2).

PCR. The 16S rRNA gene was amplified in a 100- $\mu$ l (total volume) reaction mixture containing PCR buffer $\left[67 \mathrm{mM}\right.$ Tris- $\mathrm{HCl}(\mathrm{pH} 8.8), 16.6 \mathrm{mM}\left(\mathrm{NH}_{4}\right)_{2} \mathrm{SO}_{4}$, $0.45 \%$ (vol/vol) Triton X-100, $200 \mu \mathrm{g}$ of gelatin per $\mathrm{ml}], 1.5 \mathrm{mM} \mathrm{MgCl}$, each deoxynucleoside triphosphate at a concentration of $200 \mu \mathrm{M}, 0.25 \mu \mathrm{M}$ primer $27 \mathrm{f}$, $0.25 \mu \mathrm{M}$ primer $1525 \mathrm{r}(17), 100 \mathrm{ng}$ of DNA, and $1 \mathrm{U}$ of $T$ th Plus DNA polymerase (Biotech International, Ltd., Perth, Australia). Negative controls that contained all of the ingredients described above except for the template DNA were included in each experiment. Each reaction mixture was overlaid with $80 \mu \mathrm{I}$ of mineral oil to prevent evaporation. 
TABLE 1. B. solanacearum strains and related bacteria studied

\begin{tabular}{|c|c|c|c|c|c|c|c|c|}
\hline Organism & Strain $^{a}$ & Location & Host & Biovar & $\begin{array}{l}\text { Division or } \\
\text { subdivision }\end{array}$ & $\begin{array}{l}\text { Year } \\
\text { isolated }\end{array}$ & Other designation $(\mathrm{s})^{a}$ & $\begin{array}{c}\text { GenBank } \\
\text { accession } \\
\text { no. }\end{array}$ \\
\hline \multirow[t]{17}{*}{ B. solanacearum } & $\mathrm{R} 288$ & $\begin{array}{l}\text { People's Republic } \\
\text { of China }\end{array}$ & Mulberry & 5 & 1 & & UW373 & U27984 \\
\hline & $\mathrm{ACH} 092$ & Australia & Ginger & 4 & 1 & 1966 & & U27985 \\
\hline & $\mathrm{ACH} 0171$ & Australia & Eggplant & 3 & 1 & 1967 & & U27986 \\
\hline & R791 & Indonesia & Tomato & 3 & 1 & 1992 & & U27987 \\
\hline & CIP365 & Philippines & Potato & 5 & 1 & & & $\mathrm{U} 28220$ \\
\hline & $\mathrm{ACH} 0732^{b}$ & Australia & Tomato & 2 & 1 & 1979 & & U27983 \\
\hline & PDDCC $1727^{\top}$ & United States & Tomato & 1 & $2 \mathrm{a}$ & & $\begin{array}{l}\text { ATCC } 1696^{\mathrm{T}}, \mathrm{K} 60^{\mathrm{T}}, \\
{\text { ACM } 3851^{\mathrm{T}}}^{\text {AC }}\end{array}$ & U28221 \\
\hline & CIP 210 & Brazil & Potato & 1 & $2 a$ & 1976 & Brazil 62,1076 & U28222 \\
\hline & R207 & Belize & Musa ABB (Moko) & 1 & $2 a$ & & & $\mathrm{U} 28223$ \\
\hline & $\mathrm{ACH} 0158$ & Australia & Potato & 2 & $2 \mathrm{a}$ & 1966 & & U28224 \\
\hline & Br 150 & United Kingdom & Solanum dulcamara & 2 & $2 \mathrm{a}$ & & & U28225 \\
\hline & CIP238 & Chile & Potato & 2 & $2 a$ & 1983 & & U28226 \\
\hline & $\mathrm{R} 634$ & Philippines & Banana (Moko) & 1 & $2 \mathrm{a}$ & 1991 & JEMOK6 & U28229 \\
\hline & R633 & Philippines & Banana (Moko) & 1 & $2 a$ & 1991 & JEMOK2 & $\mathrm{U} 28230$ \\
\hline & R639 & Philippines & Banana (Bugtok) & 1 & $2 \mathrm{a}$ & 1991 & JEBUG1 & U28231 \\
\hline & $\mathrm{R} 780$ & Indonesia & Potato & N2 & $2 b$ & 1992 & & U28232 \\
\hline & R142 & Indonesia & Clove & 2 & $2 b$ & 1985 & & $\mathrm{U} 28233$ \\
\hline \multirow[t]{3}{*}{$\mathrm{BDB}$} & R506 & Indonesia & Banana & & $2 b$ & & T340 & U28234 \\
\hline & R233 & Indonesia & Banana & & $2 b$ & 1986 & T379 & $\mathrm{U} 28235$ \\
\hline & R223 & Indonesia & Banana & & $2 b$ & 1986 & T439 & U28236 \\
\hline \multirow[t]{2}{*}{ P. syzygii } & $\mathrm{R} 001^{\mathrm{T}}$ & Indonesia & Clove & & $2 b$ & 1980 & & U28237 \\
\hline & R058 & Indonesia & Clove & & $2 b$ & 1985 & & $\mathrm{U} 28238$ \\
\hline
\end{tabular}

"Abbreviations: R, Rothamsted Experimental Station, Harpenden, Hertfordshire, United Kingdom; ACH, A. C. Hayward, Department of Microbiology, Centre for Bacterial Diversity and Identification, The University of Queensland, St. Lucia, Australia; ACM, Australian Collection of Microorganisms, Department of Microbiology, Centre for Bacterial Diversity and Identification, The University of Queensland, St. Lucia, Australia; CIP, International Potato Center, Lima, Peru; ATCC, American Type Culture Collection, Rockville, Md.; PDDCC, Culture Collection of Plant Diseases Division, New Zealand Department of Scientific and Industrial Research, Auckland, New Zealand.

${ }^{b}$ Atypical biovar 2 strain.

PCR amplifications were performed with a Perkin-Elmer Cetus model 480 thermal cycler programmed as follows: an initial denaturation step at $96^{\circ} \mathrm{C}$ for 3 min, followed by 28 cycles consisting of $48^{\circ} \mathrm{C}$ for $1 \mathrm{~min}, 72^{\circ} \mathrm{C}$ for $2 \mathrm{~min}$, and $93^{\circ} \mathrm{C}$ for $1 \mathrm{~min}$, with a final extension step at $48^{\circ} \mathrm{C}$ for $1 \mathrm{~min}$ and at $72^{\circ} \mathrm{C}$ for $5 \mathrm{~min}$ to allow all extension products to be completed.

The PCR products were examined by electrophoresing $5 \mu \mathrm{l}$ of each PCR product in $1 \%$ agarose gels at $4 \mathrm{~V} / \mathrm{cm}$ for $10 \mathrm{~min}$ and then at $10 \mathrm{~V} / \mathrm{cm}$ for $30 \mathrm{~min}$. The PCR amplification products were visualized by staining with ethidium bromide.

The remaining $95 \mu \mathrm{l}$ of each PCR product was purified by using a Promega Magic PCR Prep DNA purification kit according to the manufacturer's instructions.

DNA sequencing. A Taq DyeDeoxy Terminator Cycle sequencing kit (Applied Biosystems, Foster City, Calif.) was used as recommended by the manufacturer with primers 27f, 357r, 519r, 907r, 926f, 1100r, 1114f, 1392r, 1406f, and 1525r (17), as well as primers $787 \mathrm{r}$ and $803 \mathrm{f} \mathrm{(29),} \mathrm{to} \mathrm{directly} \mathrm{determine} \mathrm{the} \mathrm{sequences}$ of purified PCR products. The extension products were purified by phenolchloroform extraction according to the manufacturer's instructions. The sequences of the products were determined with an Applied Biosystems model 373A DNA sequencer.

Analysis of data. The $16 \mathrm{~S}$ rDNA sequences of different strains of B. solanaceanum, $P$. syzygii, and the BDB were manually aligned with the sequences of the type strain of $B$. solanaceanum (strain PDDCC1727) and other species belonging to the beta subclass of the Proteobacteria by using the AE2 sequence editor (20). The evolutionary distances between sequences were computed by using the algorithm of Jukes and Cantor (15) and the DNADIST program of the PHYLIP phylogenetic analysis software package (version 3.5) (7). A dendrogram was constructed from evolutionary distance values by using the neighbor-joining method of Saitou and Nei (26) contained in the NEIGHBOR program of PHYLIP, version 3.5. The most-parsimonious tree was also constructed by using the PAUP software package (33). The topologies of the distance and parsimony trees were tested by 100 bootstrap resamplings of the data.

Nucleotide sequence accession numbers. The nucleotide sequences determined in this study have been deposited in the GenBank data library under the accession numbers shown in Table 1.

\section{RESULTS}

We determined nearly complete 16S rDNA sequences for 19 isolates of $B$. solanaceanum, three isolates of the $\mathrm{BDB}$, and two isolates of $P$. syzygii. The dendrogram (Fig. 1) that was produced by comparing 1,422 nucleotide positions (all ambiguous nucleotides were omitted from the comparisons) contains two divisions, which is consistent with the findings of Cook et al. (3) and $\mathrm{Li}$ et al. (18). B. solanacearum biovar 3, 4, and 5 strains and an aberrant biovar 2 isolate (strain $\mathrm{ACH} 0732$ ) made up division 1 , and $B$. solanacearum biovar 1,2, and N2 strains, the BDB strains, and $P$. syzygii strains made up division 2 . Two subdivisions were recognized within division 2 , and these subdivisions were designated subdivisions $2 \mathrm{a}$ and $2 \mathrm{~b}$. Subdivision $2 \mathrm{~b}$ comprised $P$. syzygii, the $\mathrm{BDB}$, and two Indonesian $B$. solanacearum isolates, strains R780 and R142. Subdivision 2a comprised all other biovar 1,2, and N2 isolates. As determined by bootstrap values, the branch point separating divisions 1 and 2 was well supported ( $100 \%$ of evolutionary distance-based trees and $92 \%$ of parsimony-based trees). However, the branch point separating the two subdivisions of division 2 was not well supported (59\% of evolutionary distance-based trees and $53 \%$ of parsimony-based trees) (Fig. 1).

The sequence differences and their positions (in the Escherichia coli numbering system [35]) are shown in Table 2. Positions 458 to 460 (UUC) and 474 (A) characterized the division 2 isolates. The nucleotides at the same positions in the division 1 isolates were ACU and $\mathrm{U}$, respectively, except in aberrant biovar 2 isolate ACH0732. Strain ACH0732 had a U at posi- 


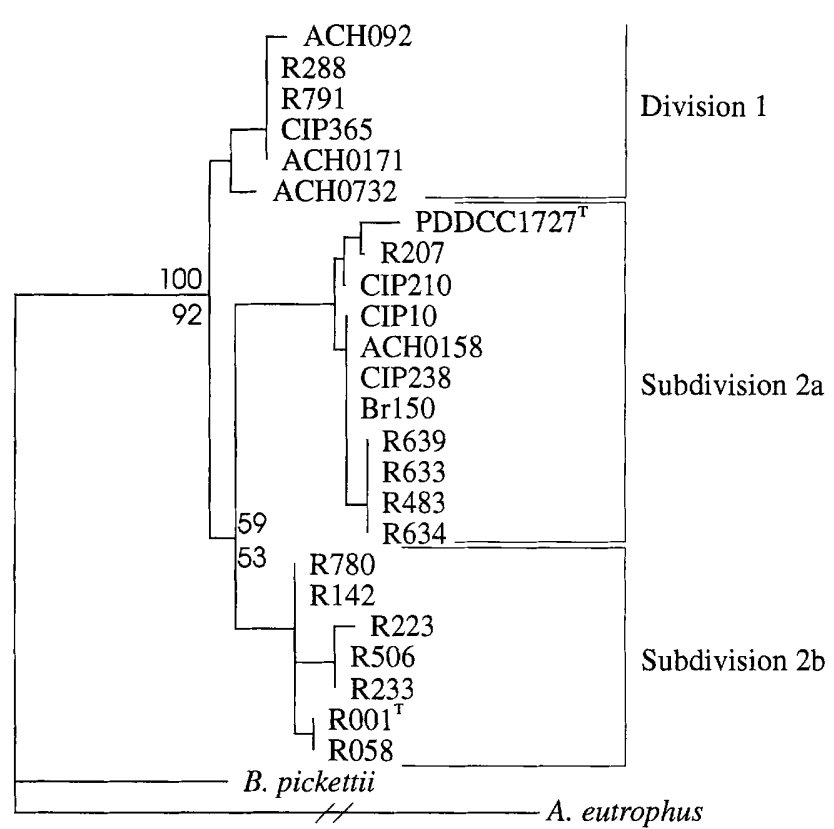

0.01

FIG. 1. Distance matrix tree showing the phylogenetic relationships of $B$. solanacearum strains and strains of the closely related organisms $P$. syzygii and the BDB based on 16S rDNA sequence comparisons. Pseudomonas pickettii and Alcaligenes eutrophus were used as outgroups in this analysis. The numbers at the branch points are the percentages of bootstrap replicates in which the clusters were found; in each case the upper value is the percentage of distance trees in which the branch point occurred, and the lower value is the percentage of parsimony trees in which the branch point occurred.

tion 458 , as did the division 2 isolates, and a $\mathrm{G}$ at position 474 (Table 2). The division 1 and subdivision $2 \mathrm{~b}$ isolates had the same nucleotides at positions 1424 (C), 1428 (A), 1456 (A), and $1472(\mathrm{U})$ and differed at these positions from the subdivision 2a isolates (Table 2). The sequences of $P$. syzygii strains were characterized by a $\mathrm{G}$ at position 328 and a deletion at position 205. The sequences of the BDB strains had unique nucleotides at positions 848 and 1441. A G at position 264 was found only in the sequence of the single biovar 4 isolate tested; the sequences of all of the other isolates examined had an $\mathrm{A}$ at this position. However, partial sequencing of other biovar 4 isolates failed to confirm that this nucleotide is biovar 4 specific (data not shown). The type strain of $B$. solanacearum, strain PDDCC1727 (= ATCC $11696=$ K60 = ACM3851), clustered in subdivision 2 a but differed from all other members of subdivision $2 \mathrm{a}$ by having the same nucleotides at positions 167 and 649 as subdivision $2 \mathrm{~b}$ strains. The sequences of isolates R483, R634, R633, and R639 differed from the sequences of all other isolates at position 1208. The sequences of isolates $\mathrm{ACH} 0732$, CIP210, R207, and PDDCC1727 ${ }^{\mathrm{T}}$ ( $\mathrm{T}=$ type strain) had a $\mathrm{U}$ at position 269 , in contrast to all other isolates, which had a $\mathrm{C}$ at this position. Strains PDDCC1727 $7^{\mathrm{T}}$ and R207 also had a U at position 1451 , while all other isolates had a $\mathrm{C}$ at this position. The sequence of BDB isolate R223 had a unique nucleotide at position 1402 .

The 16S rDNA sequences of the division 1 isolates exhibited levels of similarity that ranged from 99.8 to $100 \%$. Within division 2 (including subdivisions $2 \mathrm{a}$ and $2 \mathrm{~b}$ ) the levels of sequence similarity ranged from 99.1 to $100 \%$. Within subdivision $2 b$, the levels of sequence similarity ranged from 99.7 to $100 \%$, and within subdivision $2 \mathrm{a}$ the levels of sequence simi- larity ranged from 99.6 to $100 \%$. The division 1 isolates exhibited an average level of sequence similarity of $99.3 \%$ (range, 99.1 to $99.5 \%$ ) with the division 2 isolates. The average level of sequence similarity for the members of the two subdivisions of division 2 was of $99.3 \%$ (range, 99.1 to $99.4 \%$ ). Division 1 isolates exhibited average levels of similarity of $99.3 \%$ (range, 99.1 to $99.4 \%$ ) and $99.4 \%$ (range, 99.2 to $99.5 \%$ ) with members of subdivisions $2 \mathrm{a}$ and $2 \mathrm{~b}$, respectively. The levels of $16 \mathrm{~S}$ rDNA sequence similarity between the $\mathrm{BDB}$ and $B$. solanacearum isolates ranged from 99.1 to $99.9 \%$. The sequences of the $B$. solanacearum $\mathrm{R} 780$ and $\mathrm{R} 142$ isolates were most similar to the sequences of the BDB strains; all of these organisms were isolated from plants in Indonesia (Table 1). The levels of sequence similarity between the $P$. syzygii isolates and the $B$. solanacearum isolates sequenced ranged from 99.2 to $99.9 \%$. Again, the $B$. solanacearum isolates which exhibited the highest levels of similarity to $P$. syzygii isolates were strains R780 and R142.

The sequences of strains ACH0158, ACH092, ACH0171, and PDDCC $1727^{\mathrm{T}}$ determined previously by Li et al. (18) were confirmed, except that one extra G occurred at position 1456 in strains PDDCC $1727^{\mathrm{T}}$ and ACH0158.

\section{DISCUSSION}

We determined the 16S rRNA gene sequences of 19 strains of $B$. solanacearum that were isolated from various hosts and geographical regions (Table 1) and represented all known biovars $(10,14)$. The results of our sequence analysis and comparisons expressed in the dendrogram in Fig. 1 confirm and extend the results of $\mathrm{Li}$ et al. (18). The two main clusters, designated divisions 1 and 2 (Fig. 1), which were identified in this study and by Li et al. (18) on the basis of $16 \mathrm{~S}$ rDNA sequences correspond to the two divisions defined by Cook et al. (3) on the basis of restriction fragment length polymorphism analysis data. Cook et al. (3) showed that the similarity coefficient based on pairwise comparisons of all restriction fragment length polymorphism groups for groups division 1 (biovars 3, 4, and 5) and division 2 (biovars 1, 2, and N2) was only $13.5 \%$.

The divergent phylogeny observed with $B$. solanacearum strains corresponds to a level of DNA reassociation that is less than the level of DNA reassociation expected within a species. Strains of the same species are expected to exhibit DNA reassociation values of more than $70 \%$ (30), whereas the levels of DNA-DNA hybridization between the members of different biovars of $B$. solanacearum have commonly been substantially less than $70 \%(23,25)$. However, Roberts et al. (25) and Palleroni and Doudoroff (23) found that the techniques used to measure levels of DNA-DNA hybridization of $B$. solanacearum strains resulted in inherent variability (25) or produced inconsistent results (23) and may therefore only be useful as a guide to the relatedness of strains. It is evident from restriction fragment length polymorphism analysis data, 16S rRNA gene sequence data, and phenotypic differences that the two divisions of $B$. solanacearum may represent subspecies, as suggested by $\mathrm{Li}$ et al. (18), or separate species. Below we refer to the species $B$. solanacearum, as currently described phenotypically, as a species complex to reflect this intraspecies variation.

B. solanacearum ACH0732, which clusters with biovars 3, 4, and 5 in division 1, was originally isolated from a tomato plant in Darwin, Northern Territory, Australia, in October 1978. The characteristics of this isolate are for the most part typical of biovar 2; strain ACH0732 produces acid from lactose, maltose, and cellobiose, but not from the hexose alcohols mannitol, sorbitol, and dulcitol, and does not produce gas from nitrate. 
TABLE 2. $16 \mathrm{~S}$ rDNA sequence differences in 24 isolates of $B$. solanacearum and related bacteria

\begin{tabular}{|c|c|c|c|c|c|c|c|c|c|c|c|c|c|c|c|c|c|c|c|c|c|}
\hline \multirow{2}{*}{ Isolate } & \multicolumn{20}{|c|}{ Nucleotide(s) at position(s) ${ }^{\alpha}$ : } & \multirow{2}{*}{$\begin{array}{l}\text { Division or } \\
\text { subdivision }\end{array}$} \\
\hline & 167 & 204 & 205 & 264 & 269 & 328 & $458-460$ & 474 & 649 & 669 & 737 & 848 & 1208 & 1402 & 1424 & 1428 & 1441 & 1451 & 1456 & 1472 & \\
\hline R288 & A & G & A & A & $\mathrm{C}$ & C & $\mathrm{ACU}$ & $\mathrm{U}$ & $\mathrm{G}$ & A & $\mathrm{U}$ & $\mathrm{C}$ & $\mathrm{C}$ & $\mathrm{C}$ & $\mathrm{C}$ & A & A & $\mathrm{C}$ & A & $\mathrm{U}$ & 1 \\
\hline $\mathrm{ACH} 092$ & A & $\mathrm{G}$ & A & G & $\mathrm{C}$ & $\mathrm{C}$ & $\mathrm{ACU}$ & $\mathrm{U}$ & $\mathrm{G}$ & A & $\mathrm{U}$ & $\mathrm{C}$ & $\mathrm{C}$ & $\mathrm{C}$ & $\mathrm{C}$ & A & A & $\mathrm{C}$ & $\mathrm{A}$ & $\mathrm{U}$ & 1 \\
\hline ACH0171 & A & G & A & A & $\mathrm{C}$ & $\mathrm{C}$ & $\mathrm{ACU}$ & $\mathrm{U}$ & $\mathrm{G}$ & A & $\mathrm{U}$ & $\mathrm{C}$ & $\mathrm{C}$ & $\mathrm{C}$ & $\mathrm{C}$ & A & A & $\mathrm{C}$ & A & $\mathrm{U}$ & 1 \\
\hline R791 & A & G & A & A & C & C & $\mathrm{ACU}$ & $U$ & G & A & $U$ & C & $\mathrm{C}$ & $\mathrm{C}$ & $\mathrm{C}$ & A & A & $\mathrm{C}$ & A & $\mathrm{U}$ & 1 \\
\hline CIP365 & A & $\mathrm{G}$ & A & A & $\mathrm{C}$ & $\mathrm{C}$ & $\mathrm{ACU}$ & $\mathrm{U}$ & $\mathrm{G}$ & A & $\mathrm{U}$ & $\mathrm{C}$ & $\mathrm{C}$ & $\mathrm{C}$ & $\mathrm{C}$ & A & A & $\mathrm{C}$ & A & $\mathrm{U}$ & 1 \\
\hline ACH0732 & A & G & A & A & $\mathrm{U}$ & C & UCU & $\mathrm{G}$ & $\mathrm{G}$ & A & $\mathrm{U}$ & C & C & $\mathrm{C}$ & C & A & A & $\mathrm{C}$ & A & $\mathbf{U}$ & 1 \\
\hline $\operatorname{PDDCC} 1727^{\mathrm{T}}$ & $\mathrm{G}$ & G & A & A & $\mathrm{U}$ & $\mathrm{C}$ & UUC & A & G & A & $\mathrm{U}$ & $\mathrm{C}$ & $\mathrm{C}$ & $\mathrm{C}$ & $\mathrm{U}$ & $\mathrm{G}$ & A & $\mathrm{U}$ & G & $\mathrm{C}$ & $2 a$ \\
\hline CIP210 & A & G & A & A & $\mathrm{U}$ & $\mathrm{C}$ & UUC & A & A & A & $\mathbf{U}$ & $\mathrm{C}$ & $\mathrm{C}$ & $\mathrm{C}$ & $\mathrm{U}$ & G & A & $\mathrm{C}$ & G & $\mathrm{C}$ & $2 \mathrm{a}$ \\
\hline R207 & A & G & A & A & $\mathrm{U}$ & $\mathrm{C}$ & UUC & A & A & A & $\mathbf{U}$ & $\mathrm{C}$ & $\mathrm{C}$ & $\mathrm{C}$ & $\mathrm{U}$ & G & A & $\mathrm{U}$ & $\mathrm{G}$ & $\mathrm{C}$ & $2 a$ \\
\hline $\mathrm{ACH} 0158$ & A & G & A & A & C & C & UUC & A & A & A & $\mathrm{U}$ & $\mathrm{C}$ & $\mathrm{C}$ & $\mathrm{C}$ & $\mathrm{U}$ & G & A & $\mathrm{C}$ & G & $\mathrm{C}$ & $2 a$ \\
\hline Br 150 & A & G & A & A & $\mathrm{C}$ & C & UUC & A & A & A & $\mathrm{U}$ & $\mathrm{C}$ & $\mathrm{C}$ & C & $\mathrm{U}$ & $\mathrm{G}$ & A & $\mathrm{C}$ & G & $\mathrm{C}$ & $2 a$ \\
\hline CIP238 & A & G & A & A & $\mathrm{C}$ & C & UUC & A & A & A & $\mathrm{U}$ & $\mathrm{C}$ & $\mathrm{C}$ & $\mathrm{C}$ & $\mathrm{U}$ & G & A & C & G & $\mathrm{C}$ & $2 a$ \\
\hline CIP10 & A & G & A & A & C & $\mathrm{C}$ & UUC & A & A & A & $\mathrm{U}$ & $\mathrm{C}$ & C & $\mathrm{C}$ & $\mathrm{U}$ & G & A & $\mathrm{C}$ & G & $\mathrm{C}$ & $2 a$ \\
\hline R483 & A & G & A & A & $\mathrm{C}$ & C & UUC & A & A & A & $\mathrm{U}$ & $\mathrm{C}$ & $\mathrm{U}$ & $\mathrm{C}$ & $\mathrm{U}$ & G & A & $\mathrm{C}$ & G & C & $2 a$ \\
\hline R634 & A & G & A & A & $\mathrm{C}$ & $\mathrm{C}$ & UUC & A & A & A & $\mathrm{U}$ & $\mathrm{C}$ & $\mathrm{U}$ & $\mathrm{C}$ & $U$ & G & A & C & G & $\mathrm{C}$ & $2 a$ \\
\hline R633 & A & $\mathrm{G}$ & A & A & $\mathrm{C}$ & C & UUC & A & A & A & $\mathrm{U}$ & $\mathrm{C}$ & $\mathrm{U}$ & $\mathrm{C}$ & $\mathrm{U}$ & $\mathrm{G}$ & A & $\mathrm{C}$ & G & $\mathrm{C}$ & $2 a$ \\
\hline R639 & A & G & A & A & C & $\mathrm{C}$ & UUC & A & A & A & $\mathrm{U}$ & $\mathrm{C}$ & $\mathrm{U}$ & $\mathrm{C}$ & $\mathrm{U}$ & G & A & $C$ & G & $\mathrm{C}$ & $2 \mathrm{a}$ \\
\hline R780 & G & G & A & A & $\mathrm{C}$ & C & UUC & A & $\mathrm{G}$ & G & $\mathrm{C}$ & $\mathrm{C}$ & $\mathrm{C}$ & $\mathrm{C}$ & $\mathrm{C}$ & A & A & $\mathrm{C}$ & A & U & $2 b$ \\
\hline R142 & G & G & A & A & $\mathrm{C}$ & $\mathrm{C}$ & UUC & A & G & $\mathrm{G}$ & $\mathrm{C}$ & $\mathrm{C}$ & $\mathrm{C}$ & $\mathrm{C}$ & C & A & A & $\mathrm{C}$ & A & $\mathrm{U}$ & $2 b$ \\
\hline R223 & G & G & A & A & $\mathrm{C}$ & $\mathrm{C}$ & UUC & A & G & G & C & $\mathrm{U}$ & C & A & $C$ & A & G & $\mathrm{C}$ & A & $\mathrm{U}$ & $2 b$ \\
\hline R506 & $\mathrm{G}$ & G & A & A & $\mathrm{C}$ & $\mathrm{C}$ & UUC & A & G & G & $\mathrm{C}$ & $\mathrm{U}$ & $\mathrm{C}$ & $\mathrm{C}$ & $C$ & A & G & C & A & $\mathrm{U}$ & $2 b$ \\
\hline R233 & G & G & A & A & $\mathrm{C}$ & $\mathrm{C}$ & UUC & A & G & $\mathrm{G}$ & $\mathrm{C}$ & $\mathrm{U}$ & $\mathrm{C}$ & $\mathrm{C}$ & C & A & G & C & A & $\mathrm{U}$ & $2 b$ \\
\hline $\mathrm{R} 001^{\mathrm{T}}$ & $\mathrm{G}$ & C & & A & $\mathrm{C}$ & G & UUC & A & $\mathrm{G}$ & $\mathrm{G}$ & $\mathrm{C}$ & $\mathrm{C}$ & $\mathrm{C}$ & C & $\mathrm{C}$ & A & A & C & A & U & $2 b$ \\
\hline R058 & G & $\mathrm{N}$ & & A & $\mathrm{C}$ & G & UUC & A & G & $\mathrm{G}$ & $\mathrm{C}$ & $\mathrm{C}$ & $\mathrm{C}$ & $\mathrm{C}$ & $\mathrm{C}$ & A & A & $\mathrm{C}$ & A & $\mathrm{U}$ & $2 b$ \\
\hline
\end{tabular}

${ }^{a} E$. coli numbering (35).

Strain $\mathrm{ACH} 0732$ produces acid from trehalose, unlike all other biovar 2 isolates found in Australia (14), and for this reason has been considered aberrant. No other biovar 2 isolates have been isolated from the Northern Territory. In Australia, biovar 2 isolates are isolated almost exclusively from potatoes or a few solanaceous weeds in southern and eastern states (11), whereas strain $\mathrm{ACH} 0732$ came from a lowland tropical region with no previous history of potato cultivation. In a comparison of whole-cell protein profiles, ACH0732 occupied a position intermediate between the clusters representing division 1 (biovars 3 and 4 ) and division 2 (biovars 1 and 2), but it was more similar to biovars 3 and 4 than to biovars 1 and 2 (19). In this study we found that $\mathrm{ACH} 0732$ has a unique nucleotide sequence at key positions 458 to 460 , as well as different nucleotides at positions 269 and 474 than those present at these positions in division 1 strains. The occurrence of an organism that has a phenotype similar to that of a biovar 2 organism but a protein profile (19) and $16 \mathrm{~S}$ rDNA sequence similar to (but distinct from) the protein profiles and $16 \mathrm{~S}$ rDNA sequences of biovar 3 and 4 strains underscores the level of heterogeneity present in the $B$. solanacearum species complex.

Two close relatives of $B$. solanacearum, the BDB, which causes blood disease of bananas in Indonesia $(6,32)$, and $P$. syzygii, which causes Sumatra disease of cloves in Indonesia, were included in this study to clarify their taxonomic status. $P$. syzygii and the BDB are found only in Indonesia (5), have similar fatty acid profiles $(25,31)$, and are serologically related $(1,25)$ to $B$. solanacearum. DNA homology studies have shown that $P$. syzygii is closely related to $B$. solanacearum (25), and partial sequencing of the $16 \mathrm{~S}$ rRNA gene has confirmed the close relationship of $B$. solanacearum, the $\mathrm{BDB}$, and $P$. syzygii (28). Partial sequencing of the $16 \mathrm{~S}$ rRNA gene of the BDB by Seal et al. (28) showed that the first 292 bases are identical to the bases found in some $B$. solanacearum isolates, including isolate R142 (which was also included in this study), and that $P$. syzygii has the same sequence as the BDB and R142 but its sequence is one base shorter. The occurrence of a deletion in $P$. syzygii (at position 205) was confirmed in this study (Table 2 ). The sequence of $P$. syzygii which we determined differs from the sequence of Seal et al. (28) by a single base at position 204 in strain R001; this strain has a $C$ rather than the $G$ which is found in all other $B$. solanacearum and BDB isolates sequenced by us and Seal et al. (28).

We found that $P$. syzygii and the BDB cluster within the $B$. solanacearum species complex (Fig. 1). P. syzygii, the BDB, and two isolates of $B$. solanacearum, strains R142 and R780, form a separate cluster within division 2 , designated subdivision $2 b$ (Fig. 1), which contains only isolates from Indonesia. Isolate $\mathrm{R} 780$ is a biovar N2 isolate and was obtained from a potato. Isolate R142 was isolated from cloves, which is not a common host of $B$. solanacearum biovar 2 isolates. This strain is an atypical biovar 2 isolate which does not belong to race 3 and exhibits the same tRNA fingerprint as the BDB, but has the host range and biochemical characteristics of $B$. solanacearum $(27,28)$.

The subgroup containing Indonesian isolates (subdivision 2b) (Fig. 1) exhibits sequence homology with division 1 isolates at positions $649,1424,1428,1456$, and 1472 (V7 and V5 region of Gray et al. [9]) and with subdivision 2a isolates at positions 458 to 460 and 474 . Division 1 isolate ACH0732 is an exception; this isolate has the same base as division 2 isolates at position 458 and has a unique base at position 474 . Furthermore, subdivision $2 \mathrm{~b}$ isolates have two unique nucleotides, at positions 669 and 737. Although the branch point between subdivisions $2 \mathrm{a}$ and $2 \mathrm{~b}$ is not stable (Fig. 1) (the bootstrap values are less than $60 \%$ ), the nucleotide positions listed above unify the group. Phenotypically, the subdivision $2 \mathrm{~b}$ organisms are divergent, and they belong to two valid species ( $B$. solanacearum and $P$. syzygii) and one species (BDB) which has not been validly described, although they have very similar $16 \mathrm{~S}$ rDNA sequences.

Despite the high levels of $16 \mathrm{~S}$ rDNA sequence similarity 
between $P$. syzygii strains and members of the $B$. solanacearum species complex, recognition of $P$. syzygii as a separate species is justified because it has a clearly distinct phenotype $(5,25)$. In contrast, the phenotype of the BDB is similar to the phenotype of $B$. solanacearum (5). In a numerical analysis of more than 70 phenotypic properties, Eden-Green (5) showed that the BDB forms a distinct phenon that is intermediate between the clusters corresponding to divisions 1 and 2 of $B$. solanacearum. Also, the symptoms of blood disease of banana in Indonesia are similar to the symptoms of the insect-transmitted Moko disease caused by strains of $B$. solanacearum (e.g., B. solanacearum race 2 strain SFR) (32). However, the nine nucleotide differences (Table 2, positions 649, 669, 737, 848, 1424, $1428,1441,1456$, and 1472 ) between the sequences of three BDB strains and three Moko disease strains of $B$. solanacearum and the phenotypic differences between these organisms provide evidence that the $\mathrm{BDB}$ is distinct from the $B$. solanacearum species complex strains that cause Moko disease in Central and South America and The Philippines. Stover and Espinoza (32) concluded that Moko disease and blood disease of banana are closely related. Moko disease-causing $B$. solanacearum strains and the BDB have independently evolved similar pathologies on jungle Heliconia species in Central America and probably on wild Musa species in southern Sulawesi (Indonesia), respectively (32). In addition, our results also suggest that both the BDB and $P$. syzygii evolved from the same progenitor organism as $B$. solanacearum, which includes the Moko disease-causing organism. It is likely that in Indonesia host specialization resulted in the phenotypically distinct species $P$. syzygii on cloves and BDB on bananas.

Eden-Green (5) hypothesized that Bugtok disease of cooking bananas in The Philippines and Moko disease of dessert bananas are caused by the same organism. Eden-Green (5) also suggested that, as the first reports of Bugtok disease predate the reported introduction of Moko disease into The Philippines, either Moko disease was introduced into The Philippines at an earlier date or Central American strains that cause Moko disease may have originated in Southeast Asia. Our results which show that Bugtok and Moko disease isolates from The Philippines have the same $16 \mathrm{~S}$ rDNA sequence and have a single unique nucleotide at position 1208 (Table 2) support Eden-Green's hypothesis that Moko and Bugtok disease organisms from The Philippines may be the same organism. However, we can make no conclusion concerning the similarity of the rest of the genomes of these organisms.

The polymorphisms found in the $16 \mathrm{~S}$ rDNAs of members of the $B$. solanacearum species complex and the levels of $16 \mathrm{~S}$ rDNA sequence similarity between members of the $B$. solanacearum species complex and related organisms (BDB and $P$. syzygii), together with the phenotypic variation among these organisms, suggest that they belong to a rapidly evolving (tachytelic) group. Alternatively, it is also possible that $B$. solanacearum, as defined phenotypically, represents more than one species. If this is the case, $B$. solanacearum would appear to be a rapidly evolving species as the strains which we compared may actually belong to different species. Further work on the DNA-DNA relatedness of strains belonging to the $B$. solanacearum species complex and related bacteria will be required to resolve this issue. The high level of variability within the $B$. solanacearum species complex and related organisms is most evident near the equator in the Americas and Southeast Asia. Martin et al. (22) found that the genetic diversity of $B$. solanacearum was greatest in the tropical lowlands of Brazil, Costa Rica, and Peru and apparently lower farther from the equator. Similarly, Southeast Asia, including Indonesia, where blood disease of bananas and Sumatra disease of cloves have evolved (13), appears to be a region where rapid evolution occurs. B. solanacearum is unique among bacterial plant pathogens because of the amount of biomass generated in the xylem vessels of susceptible plant hosts. In many parts of the lowland tropics access to crop plant and weed hosts is uninterrupted by seasonal variation, and the bacterial biomass is proportionately greater than the bacterial biomass observed in areas where hosts are not as abundant.

Cook et al. (3) concluded that members of their division 2 , equivalent to our subdivision $2 \mathrm{a}$, may have originated in the Americas and that members of division 1 may have originated in Asia. The occurrence of biovar 2 isolates of the $B$. solanacearum species complex in Indonesian subdivision $2 \mathrm{~b}$ casts doubt on this proposal. The Indonesian isolates of $B$. solanacearum belonging to division 2 have $16 \mathrm{~S}$ rDNA sequences that are very similar to BDB and $P$. syzygii sequences. The latter two organisms are found only in Indonesia and must therefore have originated in Indonesia. It is also likely that the $B$. solanacearum strains belonging to subdivision $2 \mathrm{~b}$ also originated in Indonesia. If all of the strains that belong to subdivision $2 b$ originated in Indonesia, then it is likely that both divisions of $B$. solanacearum originated in Asia. To further clarify the complex phylogenetic relationships of this closely related group of organisms, other genes are being sequenced.

\section{ACKNOWLEDGMENTS}

This study was supported in part by ACIAR project PN9015. M.T. acknowledges the financial assistance of a scholarship from the Ministry of Culture and Higher Education of the Islamic Republic of Iran.

Many of the cultures used in this study were gifts from E. R. French, International Potato Center, Lima, Peru. We thank Susan Seal for many helpful discussions and for the use of her culture collection and laboratory to complete DNA extractions.

\section{REFERENCES}

1. Baharuddin, B., K. Rudolph, and F. Niepold. 1994. Production of monospecific antiserum against the blood disease affecting banana and plantain. Phytopathology 84:570-575.

2. Boucher, C. A., F. Van Gijsegem, P. Barberis, A. M. Arlat, and C. Zischek 1987. Pseudomonas solanacearum genes controlling both pathogenicity on tomato and hypersensitivity on tobacco are clustered. J. Bacteriol. 169:56265632 .

3. Cook, D., E. Barlow, and L. Sequeira. 1989. Genetic diversity of Pseudomonas solanacearum: detection of restriction fragment length polymorphisms with DNA probes that specify virulence and hypersensitive response. Mol. Plant Microbe Intraction 2:113-121.

4. Cook, D., E. Barlow, and L. Sequeira. 1991. DNA probes as tools for study of host-pathogen evolution: the example of Pseudomonas solanacearum, p. 103-108. In H. Hennecke and D. P. S. Verma (ed.), Advances in molecular genetics of plant-microbe interactions, vol. 1. Kluwer, Dordrecht, The Netherlands.

5. Eden-Green, S. J. 1994. Diversity of Pseudomonas solanacearum and related bacteria in South East Asia: new direction for moko disease, p. 25-34. In A. C. Hayward and G. L. Hartman (ed.), Bacterial wilt: the disease and its causative organism, Pseudomonas solanacearum. CAB International, Wallingford, United Kingdom.

6. Eden-Green, S. J., and H. Sastraatmadja. 1990. Blood disease present in Java. FAO Plant Prot. Bull. 38:49-50.

7. Felsenstein, J. 1993. PHYLIP (phylogeny inference package), version 3.5c. Department of Genetics, University of Washington, Seattle.

8. Gillis, M., V. Tran Van, R. Bardin, M. Goor, P. Hebbar, A. Willems, P. Segers, K. Kersters, T. Heulin, and M. P. Fernandez. 1995. Polyphasic taxonomy in the genus Burkholderia leading to an emended description of the genus and proposition of Burkholderia vietnamiensis sp. nov. for $\mathrm{N}_{2}$-fixing isolates from rice in Vietnam. Int. J. Syst. Bacteriol. 45:274-289.

9. Gray, M. W., D. Sankoff, and R. J. Cedergren. 1984. On the evolutionary descent of organisms and organelles: a global phylogeny based on highly conserved structural core in small subunit ribosomal RNA. Nucleic Acids Res. 12:5837-5852.

10. Hayward, A. C. 1964. Characteristics of Pseudomonas solanacearum. J. Appl. Bacteriol. 27:265-277.

11. Hayward, A. C. 1975. Biotypes of Pseudomonas solanacearum in Australia. Australas. Plant Pathol. Soc. Newsl, 4:9-11.

12. Hayward, A. C. 1991. Biology and epidemiology of bacterial wilt caused by 
Pseudomonas solanacearum Annu. Rev, Phytopathol 29:65-87.

13. Hayward, A. C. 1994. Pseudomonads infecting Musa spp. and clove (Syzygium aromaticum) in South East Asia: phylogeny and nomenclature of the causative agents and significance in plant quarantine. Australas. Plant Pathol. 23:163-169.

14. Hayward, A. C. 1994. Systematics and phylogeny of Pseudomonas solanacearum and related bacteria, p. 123-136. In A. C. Hayward and G. L. Hartman (ed.), Bacterial wilt: the disease and its causative organism, Pseudomonas solanacearum. CAB International, Wallingford, United Kingdom.

15. Jukes, T. H., and C. R. Cantor. 1969. Evolution of protein molecules, p. 21-132. In H. N. Munro (ed.), Mammalian protein metabolism. Academic Press, New York.

16. Kelman, A. 1954. The relationship of pathogenicity in Pseudomonas solanacearum to colony appearance on a tetrazolium medium. Phytopathology 44:693-695.

17. Lane, D. J. 1991. 16S/23S rRNA sequencing, p. 115-147. In E. Stackebrandt and M. Goodfellow (ed.), Nucleic acid techniques in bacterial systematics. John Wiley and Sons, Brisbane, Australia.

18. Li, X., M. Dorsch, T. Del Dot, L. I. Sly, E. Stackebrandt, and A. C. Hayward. 1993. Phylogenetic studies of the rRNA group II pseudomonads based on 16S rRNA gene sequences. J. Appl. Bacteriol. 74:324-329.

19. Li, X., and A. C. Hayward. 1994. Bacterial whole cell protein profiles of the rRNA group II pseudomonads. J. Appl. Bacteriol. 77:308-318.

20. Maidak, B. L., N. Larsen, M. J. McCaughey, R. Overbeek, G. J. Olsen, K. Fogel, J. Blandy, and C. R. Woese. 1994. The Ribosomal Database Project. Nucleic Acids Res. 22:3485-3487.

21. Marmur, J. 1961. A procedure for the isolation of deoxyribonucleic acid from microorganisms. J. Mol. Biol. 3:208-218.

22. Martin, C., E. R. French, and U. Nydegger. 1982. Strains of Pseudomonas solanacearum affecting Solanaceae in the Americas. Plant Dis. 66:458-460.

23. Palleroni, N. J., and M. Doudoroff. 1971. Phenotypic characterization and deoxyribonucleic acid homologies of Pseudomonas solanacearum. J. Bacteriol. 107:690-696.

24. Palleroni, N. J., R. Kunisawa, R. Contopoulou, and M. Doudoroff. 1973.
Nucleic acid homologies in the genus Pseudomonas, Int. J. Syst. Bacteriol. 23:333-339.

25. Roberts, S. J., S. J. Eden-Green, P. Jones, and D. J. Ambler. 1990. Pseudomonas syzygii sp. nov., the cause of Sumatra disease of cloves. Syst. Appl. Microbiol. 13:34-43.

26. Saitou, N., and M. Nei. 1987. The neighbour-joining method: a new method for reconstructing phylogenetic trees. Mol. Biol. Evol. 4:406-425.

27. Seal, S. E., L. A. Jackson, and M. J. Daniels. 1992. Use of tRNA consensus primers to indicate subgroups of Pseudomonas solanacearum by polymerase chain reaction amplification. Appl. Environ. Microbiol. 58:3759-3761.

28. Seal, S. E., L. A. Jackson, J. P. W. Young, and M. J. Daniels. 1993. Differentiation of Pseudomonas solanacearum, Pseudomonas syzygii, Pseudomonas pickettii and the blood disease bacterium by partial 16S rRNA sequencing: construction of oligonucleotide primers for sensitive detection by polymerase chain reaction. J. Gen. Microbiol. 139:1587-1594.

29. Stackebrandt, E., and O. Charfreitag. 1990. Partial 16S rRNA primary structure of five Actinomyces species: phylogenetic implications and development of an Actinomyces israelii-specific oligonucleotide probe. J. Gen. Microbiol. 136:37-43.

30. Stackebrandt, E., and B. M. Goebel. 1994. Taxonomic note: a place for DNA-DNA reassociation and $16 \mathrm{~S}$ rRNA sequence analysis in the present species definition in bacteriology. Int. J. Syst. Bacteriol. 44:846-849.

31. Stead, D. E. 1992. Grouping of plant-pathogenic and some other Pseudomonas spp. by using cellular fatty acid profiles. Int. J. Syst. Bacteriol, 42:281295.

32. Stover, R. H., and A. Espinoza. 1992. Blood disease of banana in Sulawesi. Fruits 47:611-613.

33. Swofford, J. 1993. PAUP: phylogenetic analysis using parsimony (version 3.1.1). Illinois Natural History Survey, Champaign.

34. Woese, C. R. 1987. Bacterial evolution. Microbiol. Rev. 51:221-271.

35. Woese, C. R., R. Gutell, R. Gupta, and H. F. Noller. 1983. Detailed analysis of the higher-order structure of $16 \mathrm{~S}$-like ribosomal ribonucleic acids. Microbiol. Rev. 47:621-669. 